\title{
Biomass and Nutrient Accumulation of Green Manuring Legumes Terminated at Different Growth Stages
}

\author{
Tamiru Hirpa $^{1 *}$, Heluf Gebrekidan ${ }^{2}$, Kindie Tesfaye $^{2}$ and Asfaw Hailemariam ${ }^{3}$ \\ ${ }^{1}$ Benishangule Gumuze Regional State Bureau of Agriculture, P O Box 30, Assosa, Ethiopia \\ ${ }^{2}$ Department of Plant Sciences, Haramaya University, P O Box 138, Dire Dawa, Ethiopia \\ ${ }^{3}$ National Soil Testing Center, P O Box 141, Addis Ababa, Ethiopia
}

\begin{abstract}
A field study was conducted at the experimental site of the Assosa Research Center, western Ethiopia, with the objective of generating information about the biomass and nutrient accumulation of four green manuring (GM) legume crops at different growth stages. Accordingly, factorial combinations of four legume crops [cowpea (Vigna unguiculata), soybean (Glycine max), and two common bean verities (Black Dessie and Awash Melka) (Phaseolus vulgaris)] and three growth stages of termination (mid-vegetative, mid-flowering and pod-setting) treatments laid in a randomized complete block design were used. Significant species by growth stage treatment interaction $(\mathrm{P} \leq 0.01)$ were observed in dry matter $(\mathrm{DM})$ concentration, and an increase in cowpea and a decrease in Awash Melka variety were observed with a delay in termination times. In addition to the species variability in total DM production, highly significant effect of growth stage at termination was also observed, and a rise in overall DM production was recorded with the development of GM crops. Cowpea recorded the highest per plant number $(5.8)$ and fresh mass of total $(0.4 \mathrm{gm})$ and effective $(0.21 \mathrm{gm})$ nodules compared to the rest, particularly at the mid-flowering stage of growth. According to the results of this study, nutrient (particularly $\mathrm{N}$ and $\mathrm{K}$ ) concentrations of shoot tissue showed a declining trend with increasing plant age. After considering the species and growth stage effects on the nutritional input or contribution of GM, it was discovered that cowpea and midflowering stage of growth outweighed the rest.
\end{abstract}

Keywords: Concentration; Nodules; Dry Matter; Input

\section{Introduction}

Unlike natural systems, in which biomass production is in equilibrium with nutrient reserves, the subsistence type of agricultural system found most often in the rainfed areas of Ethiopia is typified by continual loss and net removal of soil nutrients which could cause a serious threat to the overall agricultural productivity and destabilize the natural resource base (Nair, 1996). The sustainability of such agricultural systems depends to a great extent on optimizing the balance between inflows and outflows of the nutrients. The use of inorganic fertilizers in achieving this balance for successful crop production, as well as its high costs and unreliable availability for resource poor farmers, is currently causing global concern due to environmental costs in agriculture. (Bohlool et al., 2004). Beyond sustainability considerations, increasing demand for and promising returns from organic products currently have made legume green manuring (GM) an important agronomic approach to combat soil fertility problems (Horst et al., 2001; Bohlool et al., 2004). Organic inputs from GM legumes could increase crop yield through improved nutrient supply/availability and improved soil-water holding capacity. Some researchers have found $\mathrm{N}$-substitution values for $\mathrm{GM}$ in excess of actual green manure $\mathrm{N}$ accumulation, suggesting that $\mathrm{GM}$ $\mathrm{N}$ is sometimes taken up more efficiently than chemical fertilizer $\mathrm{N}$ or that GM modifies the soil environment, crop growth, or both such that greater crop $\mathrm{N}$ uptake is possible (Yadav et al., 2000). Therefore, cropping systems which include legumes as green manure could be the most efficient.

Residues of GM legume, unlike fertilizer N sources, have different effects that vary according to crop species and development stage. The chemical composition of the organic materials added into the soil as green manure has a great effect on the net $\mathrm{N}$ release from material or immobilization of soil mineral $\mathrm{N}$. Utilization of green manure $\mathrm{N}$ may thus be enhanced through measures that deliberately affect the chemical composition of the materials incorporated into the soil. The chemical composition of plant material is highly affected by the developmental stage of the plant (Dahlin et al., 2005). In the case of green manure, management options which influence the developmental stage, such as cutting, could be used to adjust the quality of the plant material at the time of incorporation so that better synchrony between GM-N release and subsequent crop demand could be achieved (Cline and Silvernail, 2001; Cherr et al., 2006). In legume crops, however, cutting practices also have a range of effects on other features, such as $\mathrm{N}_{2}$-fixation activity and abortion of nodules and roots (Wivstad, 1996). Thus, green manure crops could be chosen and managed with the aim of manipulating their quality.

According to Tandojam (2002) the selection of suitable legume species and age at termination determines the amount of biomass, $\mathrm{N}$ accumulation and the rate of liberation of nutrients in available forms. Termination or the soil incorporation date of GM crops could affect the fraction of plant biomass (leaf, stem, reproductive, or senesced tissue) and $\mathrm{N}$ if the GM responds to late-season changes in weather conditions (Cherr et al., 2006). According to Cline and Silvernail (2001) and Sainju and Singh (2001), increasing the length of the GM growing season, may or may not increase GM biomass and $\mathrm{N}$ content. Kong et al. (1993), however, have reported that the amount of biomass and $\mathrm{N}$ provided by the GM crops varies according to the growth stage at the time of soil 
incorporation. Cavigelli and Thien (2003), on the other hand, suggested that plant type seems more important than residue application rate in affecting soil $\mathrm{P}$ availability, whereas others have reported that residue application rate is more important than plant type (Bumaya and Naylor, 1988; Li et al., 1990). Ratilla and Escalada (2006), however, did not observe any significant effect of species and timing of field legume incorporation.

The efficiency of GM crops in improving soil conditions could generally be increased through correct selection of the GM crops with higher capacity and by identifying the growth stage at which maximum topgrowth and $\mathrm{N}_{2}$-fixation could be achieved (Cline and Silvernail, 2001). Knowledge of GM crop DM yield and nutrient accumulation dynamics during the growth period could, therefore, provide farmers with management options aimed at maximizing the DM production for green manure and $\mathrm{N}$ for a subsequent crop. Such manipulation of residue quality could facilitate better synchrony between GM-N release and demand by a subsequent crop, thereby conserving $\mathrm{N}$ within the agricultural ecosystem (Odhiambo and Bomke, 2001). With regard to changes in biomass production and nutrient composition dynamics, most reported studies so far have been based on values of GM biomass and $\mathrm{N}$ content at a certain growth stage (Isse et al., 1999; Somado and Sahrawat, 2007). Sampling of different green manure crops at their varied phenological stages, however, could provide much more meaningful information for selection of appropriate GM crop and development of residue management strategies. In this context, it is important to study the relationships between residual attributes of different legumes and their different phonological stages. This study was, therefore, initiated to generate information about GM biomass yield and the nutrient accumulation of four legume species terminated at their different phenological stages in the soil and climatic conditions of areas around Assosa.

\section{Materials and Methods}

\subsection{Description of the Study Area}

The study was carried out in 2007 at the experimental site of the Assosa Research Center, western Ethiopia. According to the classification of EARO (1999), the agroclimate of the area falls under sub-humid lowland with a mono-modal rainfall pattern. The area receives an annual rainfall of $1275 \mathrm{~mm}$. The annual mean maximum temperature reaches $28{ }^{\circ} \mathrm{C}$ while the mean minimum temperature is $15^{\circ} \mathrm{C}$. Rainfall and weather data during the growing season are presented in Table 1 . The dominant soil at and around the Research Center is reddish brown, Nitosols, which, according to pre-sowing soil test results, is low in fertility especially in $\mathrm{N}, \mathrm{P}$ and organic matter (Table 2).

Table 1. Mean monthly weather data for Assosa in the 2007 cropping season.

\begin{tabular}{|c|c|c|c|c|c|c|}
\hline \multirow[t]{2}{*}{ Month } & \multirow{2}{*}{ Rainfall (mm) } & \multicolumn{2}{|c|}{ Mean temperature $\left({ }^{\circ} \mathrm{C}\right)$} & \multirow{2}{*}{$\begin{array}{l}\text { Relative } \\
\text { humidity (\%) }\end{array}$} & \multirow{2}{*}{$\begin{array}{l}\text { Evapo- } \\
\text { transpiration } \\
\left(\mathrm{mm} \mathrm{day}^{-1}\right)\end{array}$} & \multirow{2}{*}{$\begin{array}{l}\text { Sunshine } \\
\text { hours day-1 }\end{array}$} \\
\hline & & Max & Min & & & \\
\hline April & 47.9 & 30.4 & 17.4 & 48.62 & 11.4 & 7.48 \\
\hline May & 82.6 & 28 & 17.3 & 50.68 & 8.9 & 5.4 \\
\hline June & 178.9 & 24.1 & 16.4 & 80.46 & 2.94 & 4.4 \\
\hline July & 178.9 & 23.2 & 15.9 & 85.56 & 2.35 & 3.32 \\
\hline August & NA & NA & NA & NA & NA & NA \\
\hline September & 224 & 24.1 & 15.6 & NA & NA & NA \\
\hline October & 147.5 & 26.7 & 13.2 & 64.62 & 3.7 & 6 \\
\hline November & 16.1 & 27.3 & 12.5 & 62.32 & 5.9 & 7.9 \\
\hline
\end{tabular}

$\mathrm{NA}=$ Data not available

Source: Assosa Metrological Service Branch Office.

\subsection{Experimental Treatments and Procedures}

A factorial combination of four legume species [cowpea, (Vigna unguiculata), soybean (Glycine max) and two common bean varieties (Black Dessie and Awash Melka) (Phaseolus vulgaris)] and three growth stages of termination viz., mid-vegetative, mid-flowering and pod-setting (Table 3 ), resulting in a total of 12 treatments, were applied on plots of $4.5 \mathrm{~m}$ by $6 \mathrm{~m}$. The experiment was laid out in two factors randomized complete block design (RCBD) and was replicated three times. Before the sowing of each crop, the land was plowed to prepare a suitable seed bed and then seeds of the GM legume crops were sown by hand drilling at spacing of 40 by $10 \mathrm{~cm}$.
Table 2. Properties of the soil as analyzed before legume planting.

\begin{tabular}{ll}
\hline Parameters & Soil test values \\
\hline $\mathrm{pH}\left(\mathrm{H}_{2} \mathrm{O}\right)$ & 5.9 \\
Organic C $\left(\mathrm{g} \mathrm{C} \mathrm{kg}^{-1}\right)$ & 19.7 \\
Total N $\left(\mathrm{g} \mathrm{kg}^{-1}\right)$ & 1.4 \\
Avilable P $\left(\mathrm{mg} \mathrm{kg}^{-1}\right)$ & 1.84 \\
$\mathrm{EC}(\mathrm{dS} / \mathrm{m})$ & 0.14 \\
$\mathrm{CEC}(\mathrm{Cmol}(+) / \mathrm{kg})$ & 25 \\
$\mathrm{~K}(\mathrm{mg} \mathrm{kg}-1)$ & 37.14 \\
$\mathrm{Ca}\left(\mathrm{Cmol}(+) / \mathrm{kg}^{-1}\right)$ & 6.34 \\
$\mathrm{Mg}\left(\mathrm{Cmol}(+) / \mathrm{kg}^{2}\right)$ & 3.67 \\
$\mathrm{Na}(\mathrm{Cmol}(+) / \mathrm{kg})$ & 0.16 \\
$\mathrm{Base} \mathrm{Sa.}(\%)$ & 40.6 \\
\hline
\end{tabular}


Table 3. Description of experimental treatments.

\begin{tabular}{|c|c|c|}
\hline $\begin{array}{l}\text { Legume } \\
\text { species }\end{array}$ & $\begin{array}{l}\text { Growth stage } \\
\text { at termination }\end{array}$ & $\begin{array}{l}\text { Description of } \\
\text { growth stage }\end{array}$ \\
\hline \multirow[t]{3}{*}{ Cowpea } & Mid-vegetative & $\begin{array}{l}8 \text { weeks after } \\
\text { emergence (WAE) }\end{array}$ \\
\hline & Mid-flowering & $11 \mathrm{WAE}$ \\
\hline & Pod-setting & $14 \mathrm{WAE}$ \\
\hline \multirow{3}{*}{$\begin{array}{l}\text { Common } \\
\text { bean }^{1}\end{array}$} & Mid-vegetative & 5 WAE \\
\hline & Mid-flowering & 8 WAE \\
\hline & Pod-setting & $11 \mathrm{WAE}$ \\
\hline \multirow{3}{*}{$\begin{array}{l}\text { Common } \\
\text { bean }^{2}\end{array}$} & Mid-vegetative & $5 \mathrm{WAE}$ \\
\hline & Mid-flowering & 8 WAE \\
\hline & Pod-setting & $11 \mathrm{WAE}$ \\
\hline \multirow[t]{3}{*}{ Soybean } & Mid-vegetative & $8 \mathrm{WAE}$ \\
\hline & Mid-flowering & $11 \mathrm{WAE}$ \\
\hline & Pod-setting & $14 \mathrm{WAE}$ \\
\hline
\end{tabular}

\subsection{Sampling, Data Collection and Analysis 2.3.1. Data Collection}

From legume crops grown in a uniform inter- and intra-row spacing of $40 \mathrm{~cm}$ by $10 \mathrm{~cm}$, the biomass yield was estimated by mowing the foliage from $1 \mathrm{~m}$ x $1 \mathrm{~m}$ quadrate of each plot at the respective termination stage. The fresh and dry foliage weights were taken immediately and after oven drying (at $105{ }^{\circ} \mathrm{C}$ for $48 \mathrm{hrs}$ ), and were later extrapolated to $\mathrm{t} \mathrm{ha}^{-1}$. To determine the per plant production of total and effective nodulation, nodules which developed a pink-brown internal color after slice opening of the nodules (Gwata et al., 2003); number and the fresh weight of each nodule were recorded after careful uprooting of 5 randomly taken plants from each plot at the respective stage of termination.

\subsubsection{Tissue Sampling and Analysis}

Shoot materials of GM legumes sampled from each plot at respective growth stages were analyzed for N, P, K and $\mathrm{Ca}$ concentrations. Nitrogen concentration in dry matter (DM) was determined using the Micro-Kheldahl method (AOAC, 1994). To determine the $\mathrm{P}$ in plant tissue, colorimetric measurement was taken, while $\mathrm{K}$ and $\mathrm{Ca}$ were determined by flame photometry and atomic absorption spectrometry respectively (Rhoades, 1982). Total GM N, P, K and Ca inputs were calculated by multiplying the concentration with the respective total DM yield.

\subsubsection{Statistical Analysis}

Analysis of variance was carried out using MSTATC statistical software followed by mean separation using the least significant difference (LSD) test and correlation test both at 1 and $5 \%$ probability levels.

\section{Results and Discussion}

\subsection{Species and Growth Stage Effects on Biomass Production}

Total fresh biomass production was observed to vary significantly $(\mathrm{P} \leq 0.01)$ among the GM legumes (Table 4). Cowpea produced the highest biomass $\left(6.85 \mathrm{t} \mathrm{ha}^{-1}\right)$ when averaged across growth stages. The biomass yield of cowpea is as high as more than double that of Black Dessie and Awash Melkas common bean varieties (Table 5). Growth stage at termination in the present study, however, did not affect $(\mathrm{P}>0.05)$ the fresh biomass weight. In this study, highly significant species by termination time treatment interaction was observed in DM content, and an increase in cowpea and a decrease in Awash Melkas were recorded with a delay in termination times (Figure 1). In this case, cowpea contained the lowest DM content, which may be attributable to dilution of the material because of large biomass production (Teasdale et al., 2004).

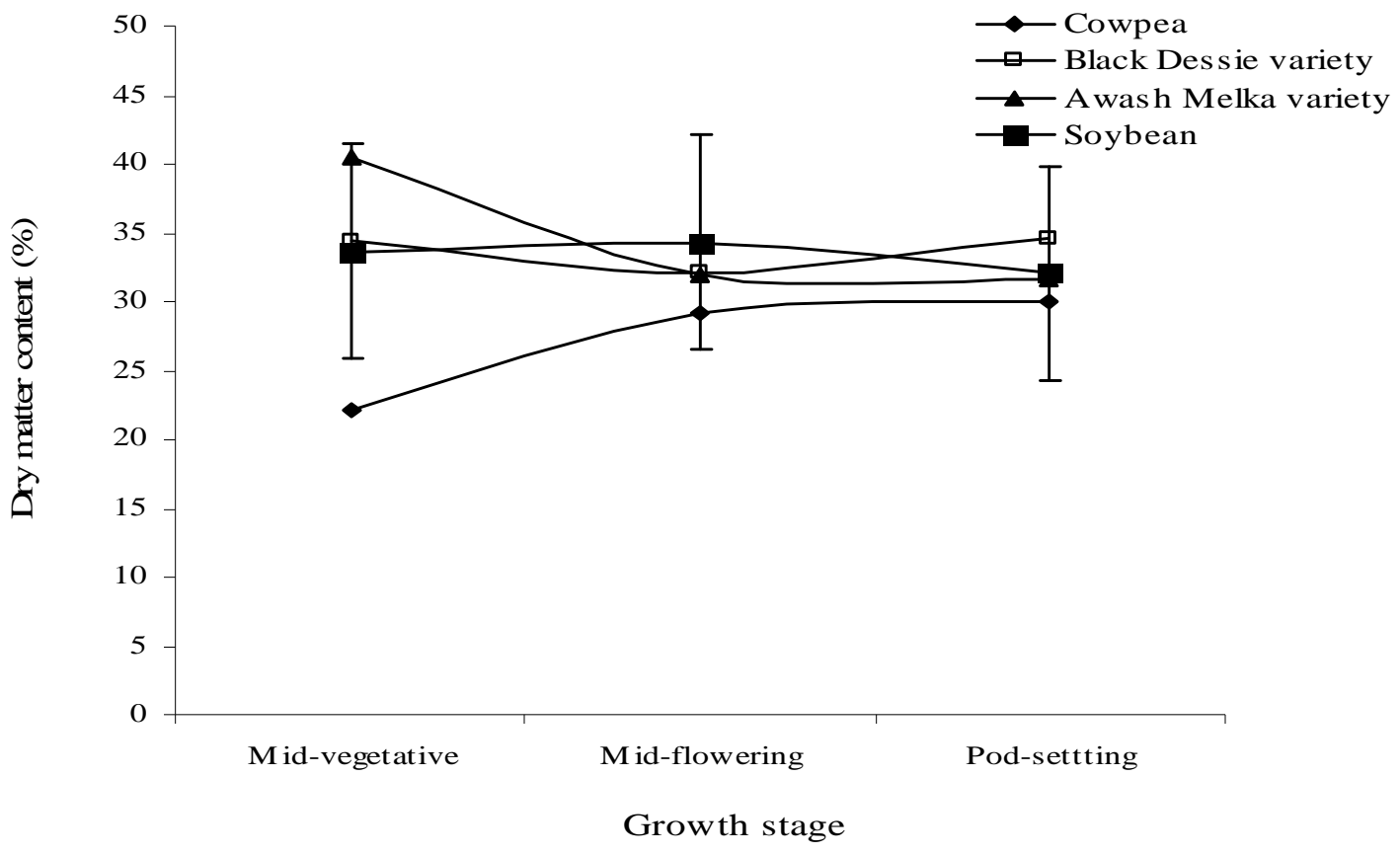

Figure 1. Interaction effect of species and growth stage on dry matter content (\%) Vertical bars represent LSD values for interaction effect at $1 \%$ probability level. 

Tamiru et al.

After considering total DM inputs of GM crops, the highest amount $(\mathrm{P} \leq 0.01)$ was recorded by cowpea $(1.86 \mathrm{t}$ $\left.\mathrm{ha}^{-1}\right)$ followed by soybean $\left(1.42 \mathrm{t} \mathrm{ha}^{-1}\right)$ when averaged across green manure termination stages (Table 5). A significant $(\mathrm{P} \leq 0.05)$ effect of growth stage at termination of GM legumes was also observed with regard to total DM input (Table 4), although a marked difference in the pattern of change in DM yield of legumes may be attributable to species variability. In this study, DM yield
East African Journal of Sciences Volume 3 (1) 18-28

increased significantly as termination was delayed from mid-vegetative to flowering stages of growth. Similarly, Brandt (1996) found the average biomass of black lentil doubled from early bud to full-bloom stages. Martin et al. (1976), however, reported that the DM yield of crotalaria reached its peak at early-flowering period, similar to the case in cowpea in this study.

Table 4. Mean square estimates for biomass yield, nodules per plant and nutrient concentrations and inputs of legume species as analyzed for two factors randomized complete block design.

\begin{tabular}{|c|c|c|c|c|}
\hline \multirow[b]{2}{*}{ Parameters studied } & \multicolumn{4}{|c|}{ Mean squares for source of variation $\dagger$} \\
\hline & Legume crop (3) & Sampling stage (2) & LS X SS (6) & Error (22) \\
\hline Fresh biomass & $36.74 * *$ & 52.97 & 1.52 & 1.46 \\
\hline$\%$ DM content & $108.56^{* *}$ & 2.23 & $47.69 * *$ & 11.59 \\
\hline Total dry matter yield & $1.96 * *$ & $0.42^{*}$ & 0.11 & 0.10 \\
\hline Nodules/plant & $19.58 * *$ & 1.18 & $2.57^{*}$ & 1.03 \\
\hline Wt. fresh nodules/plant & $0.05^{* *}$ & $0.03^{* *}$ & 0.01 & 0.004 \\
\hline Effective nodules/plant & $5.14^{* *}$ & 0.88 & $0.92^{*}$ & 0.33 \\
\hline Wt. effective nodules/plant & $0.05^{* *}$ & $0.02^{* *}$ & $0.008^{*}$ & 0.003 \\
\hline$\% \mathrm{~N}$ concentration & $1.29 * *$ & $0.20^{*}$ & $0.33^{* *}$ & 0.05 \\
\hline$\% \mathrm{P}$ concentration & $0.03 * *$ & $0.009 *$ & $0.006^{*}$ & 0.003 \\
\hline$\% \mathrm{~K}$ concentration & 0.32 & $1.16^{*}$ & 1.16 & 0.29 \\
\hline$\% \mathrm{Ca}$ concentration & $6.72 * *$ & 2.13 & 1.26 & 1.04 \\
\hline Total $\mathrm{N}$ input & $1642.40^{* *}$ & $333.52^{*}$ & 215.11 & 101.08 \\
\hline Total P input & $16.19 * *$ & 2.31 & 2.34 & 2.15 \\
\hline Total $\mathrm{K}$ input & $397.79 *$ & 73.01 & 79.56 & 101.76 \\
\hline Total Ca input & $5953.38 * *$ & $2006.86 * *$ & 501.97 & 237.84 \\
\hline
\end{tabular}

${ }^{1}$ Black Dessie Variety, ${ }^{2}$ Awas Melka V ariety, + Figures in parenthesis $=$ degrees of freedom; $*$ Significant at $P=0.05 ; * *=$ Significant at $P=0.01$.

Table 5. Effects of sampling stages on fresh biomass and total dry matter production of the legume species.

\begin{tabular}{|c|c|c|c|c|}
\hline \multirow[b]{2}{*}{ Legume species (LS) } & \multicolumn{3}{|c|}{ Growth stage (GS) } & \multirow[b]{2}{*}{ Mean* } \\
\hline & Mid-vegetative & Mid-flowering & Pod-setting & \\
\hline \multicolumn{5}{|c|}{ Fresh biomass $(\mathrm{FB})$ production $\left(\mathrm{t} \mathrm{ha}^{-1}\right)$} \\
\hline Cowpea & 7.31 & 6.87 & 6.37 & $6.85 a$ \\
\hline Common bean ${ }^{1}$ & 1.77 & 2.42 & 3.58 & $2.59 \mathrm{c}$ \\
\hline Common bean ${ }^{2}$ & 1.74 & 2.90 & 3.04 & $2.56 \mathrm{c}$ \\
\hline Soybean & 3.64 & 3.89 & 5.44 & $4.32 \mathrm{~b}$ \\
\hline Mean & 3.62 & 4.02 & 4.61 & \\
\hline \multicolumn{5}{|c|}{ Total dry matter (DM) production $\left(\mathrm{t} \mathrm{ha}^{-1}\right)$} \\
\hline Cowpea & 1.60 & 2.10 & 1.90 & $1.86 a$ \\
\hline Common bean ${ }^{1}$ & 0.61 & 0.78 & 1.24 & $0.87 \mathrm{c}$ \\
\hline Common bean ${ }^{2}$ & 0.90 & 0.93 & 0.94 & $0.92 \mathrm{c}$ \\
\hline Soybean & 1.21 & 1.33 & 1.74 & $1.42 \mathrm{~b}$ \\
\hline Mean* & $1.08 \mathrm{~b}$ & $1.28 \mathrm{ab}$ & $1.42 \mathrm{a}$ & \\
\hline LSD & LS (FB) & GS (FB) & LS (DM) & GS (DM) \\
\hline$(0.01)$ & 1.60 & NS & 0.43 & NS \\
\hline$(0.05)$ & - & NS & - & 0.27 \\
\hline
\end{tabular}

\subsection{Nodulation Pattern of Legumes at Different Phonological Stages}

Nodulation of legumes has been used by many workers as an indirect measurement (indicator) of $\mathrm{N}_{2}$-fixation (Johnson and Hume, 1983; Wolyn et al., 1989). In this study, significant $(\mathrm{P} \leq 0.05)$ species by growth stage treatment combined effect was observed in the total number of root nodules whereby cowpea at midflowering stage of growth recorded the top amount, and declining trends were observed for the remaining species in the subsequent samplings (Table 6), ascribable to genetic variation and to $\mathrm{N}_{2}$-fixing ability involving both 
legume species and rhizobium components of the symbiotic association (Sanginga et al., 2000). A trend similar to the total number of nodules was also observed in nodule fresh mass while considering the effects of species variability and growth stage (Figure 2). Similar results were reported by Elahi et al. (2004) who observed a decline in number and fresh weight of nodules after the flowering stage of growth in mungbean cultivars.

Significant $(\mathrm{P} \leq 0.05)$ interaction effects of species and growth stage treatments were also observed in this study both in the number and weight of effective nodules (Table 4), where cowpea and soybean recorded their maximum number and mass of effective nodules at the mid-flowering stage of growth and both common bean varieties recorded their maximum at the mid-vegetative stage of growth (Table 7). The number and weight of effective nodules in this study are found to be highly correlated with the number and weight of total nodules ( $\mathrm{r}$ $=0.91$ and $\mathrm{r}=0.75$, respectively) (Table 9). Generally declining values of indirect measures of $\mathrm{N}_{2}$-fixation (nodulation pattern) after the flowering stage of growth have been documented extensively (Swaraj and Garay, 1977; Johnson and Hume, 1983; Wolyn et al., 1989). The Number and mass of total and effective nodules were found to correlate more to the total phytomass $\mathrm{N}$ input than to change in DM yield with plant development (Table 8), attributable to sink strength (e.g., nodules versus pods) (Maschner, 1995).

Table 6. Interaction effects of species and growth stage on number of total nodules per plant.

\begin{tabular}{|c|c|c|c|c|}
\hline \multirow[b]{2}{*}{ Legume species (LS) } & \multicolumn{3}{|c|}{ Growth stage (GS) } & \multirow[b]{2}{*}{ Mean } \\
\hline & Mid-vegetative & Mid-flowering & Pod-setting & \\
\hline Cowpea & $3.2 \mathrm{~cd}$ & $5.8 \mathrm{a}$ & $5.2 \mathrm{ab}$ & 4.7 \\
\hline Common bean ${ }^{1}$ & $2.3 \mathrm{cde}$ & $1.9 \mathrm{de}$ & $1.4 \mathrm{e}$ & 1.9 \\
\hline Common bean ${ }^{2}$ & $2.2 \mathrm{cde}$ & $1.1 \mathrm{e}$ & $1.1 \mathrm{e}$ & 1.5 \\
\hline Soybean & $3.5 \mathrm{~cd}$ & $3.9 \mathrm{c}$ & $3.4 \mathrm{cde}$ & 3.3 \\
\hline Mean & 2.8 & 3.2 & 2.5 & \\
\hline LSD & LS X GS & & & \\
\hline (0.01) & NS & & & \\
\hline$(0.05)$ & 1.72 & & & \\
\hline
\end{tabular}

$V$ alues followed by the same letter are non-significant at $5 \%$ probability level.

${ }^{1}$ Black Dessie V ariety, ${ }^{2}$ Awas Melka V ariety, NS=non-significant; LSXGS=treatment interaction

Table 7. Interaction effects of species and growth stage on number and fresh weight $(\mathrm{g})$ of effective nodules per plant.

\begin{tabular}{|c|c|c|c|c|}
\hline \multirow[b]{2}{*}{ Legume species (LS) } & \multicolumn{3}{|c|}{ Growth stage (GS) } & \multirow[b]{2}{*}{ Mean } \\
\hline & Mid-vegetative & Mid-flowering & Pod-setting & \\
\hline \multicolumn{5}{|c|}{ Nodule number $(\mathrm{NN}) /$ plant } \\
\hline Cowpea & $1.2 \mathrm{bcd}$ & $2.2 \mathrm{a}$ & $1.9 \mathrm{ab}$ & 1.8 \\
\hline Common bean ${ }^{1}$ & $0.9 \mathrm{cde}$ & $0.0 \mathrm{e}$ & $0.0 \mathrm{e}$ & 0.3 \\
\hline Common bean ${ }^{2}$ & $0.9 \mathrm{cde}$ & $0.0 \mathrm{e}$ & $0.0 \mathrm{e}$ & 0.3 \\
\hline Soybean & $1.7 \mathrm{abc}$ & 1.9abc & $0.7 \mathrm{de}$ & 1.4 \\
\hline Mean & 1.2 & 1.0 & 0.6 & \\
\hline \multicolumn{5}{|c|}{ Fresh weight (FW) of nodules ( $\mathrm{g} /$ plant) } \\
\hline Cowpea & $0.13 \mathrm{abc}$ & $0.21 \mathrm{a}$ & $0.16 \mathrm{ab}$ & 0.17 \\
\hline Common bean ${ }^{1}$ & $0.10 \mathrm{bc}$ & $0.00 \mathrm{~d}$ & $0.00 \mathrm{~d}$ & 0.03 \\
\hline Common bean ${ }^{2}$ & $0.10 \mathrm{bc}$ & $0.00 \mathrm{~d}$ & $0.00 \mathrm{~d}$ & 0.03 \\
\hline Soybean & $0.22 \mathrm{a}$ & $0.18 \mathrm{ab}$ & $0.07 \mathrm{~cd}$ & 0.15 \\
\hline Mean & 0.14 & 0.10 & 0.06 & \\
\hline LSD & NN (LSX GS) & FW (LSX GS) & & \\
\hline$(0.01)$ & NS & NS & & \\
\hline$(0.05)$ & 0.97 & 0.09 & & \\
\hline
\end{tabular}

Means within a row or column followed by the same letter are not significantly different at the specified probability levels.

${ }^{1}$ Black Dessie V ariety, ${ }^{2}$ Awas Melka V ariety 


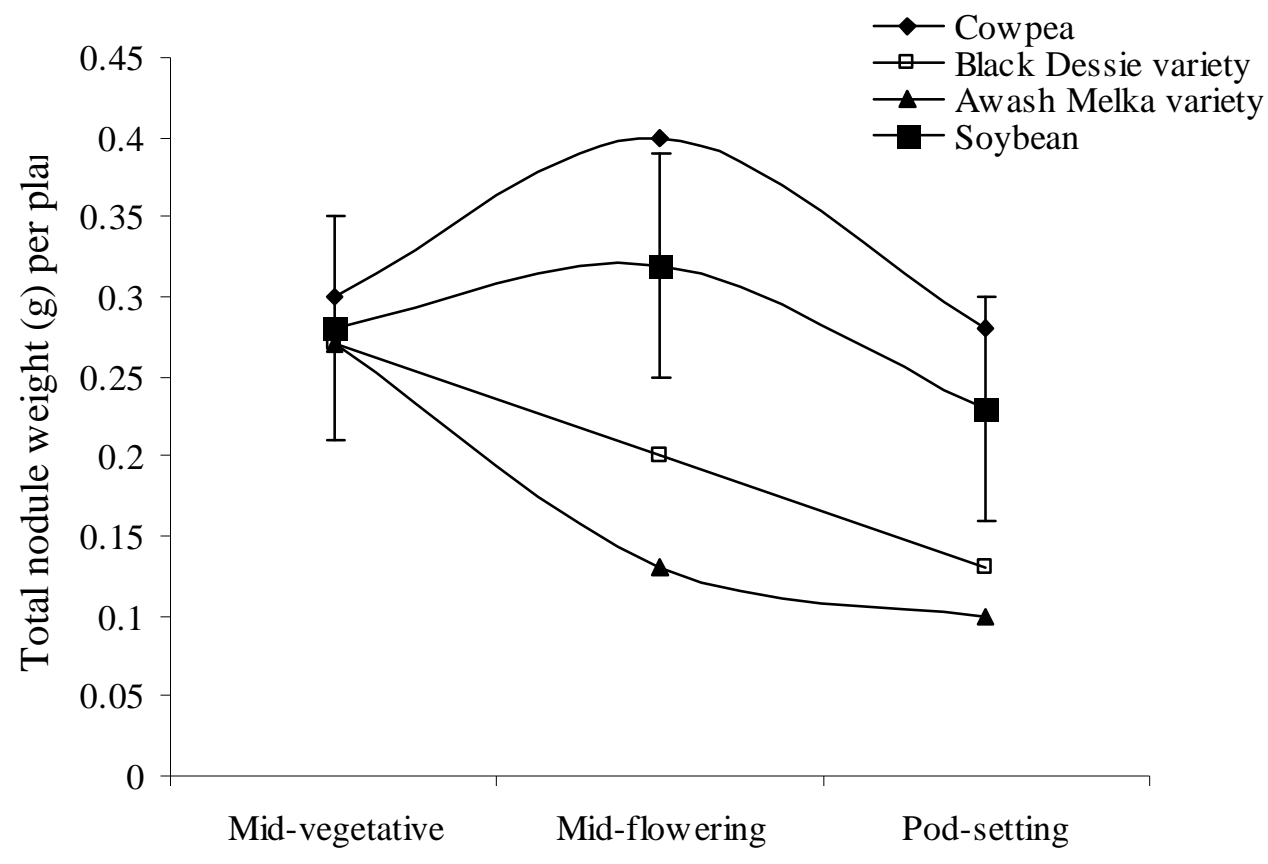

Growth stage

Figure 2. Effect of growth stage of legumes on fresh weight (g) of total nodules per plant Vertical bars represent LSD values for growth stage effect at $1 \%$ probability level.

\subsection{Effect of Legume Growth Stage on Nutrient Composition and Input}

\subsubsection{Nitrogen Content and Total Input}

In this study, a species by termination stage interaction effect $(\mathrm{P} \leq 05)$ on shoot tissue $\mathrm{N}$ concentration was observed. Both common bean varieties recorded a peak in $\mathrm{N}$ content at the vegetative growth stage after which it nearly stabilized with a further delay in termination (Figure 3). Soybean also followed a trend similar to the former crops in its $\mathrm{N}$ concentration, but was found to be the lowest throughout the growing season. The $\mathrm{N}$ concentration of cowpea, which was the lowest at the early growth phase, rose at the mid-flowering stage and declined thereafter, corresponding to nodulation pattern, which most likely is an expression of sink competition for photosynthates between the developing pods and the $\mathrm{N}_{2-}$ fixing root nodules (Marschner, 1995). The findings of this study, however, contradicted the observations made by Sainju et al. (2001) who observed on kill date effect on $\mathrm{N}$ concentration of hairy vetch and winter weeds.
The total $\mathrm{N}$ input or contribution, the product of tissue $\mathrm{N}$ concentration and total DM yield from GM legumes showed a marked difference $(\mathrm{P} \leq 0.01)$ between legume species grown (Table 4), corresponding to the differential biomass production (Table 5 and 8). In this regard, maximum DM production in cowpea contributed to a great extent to the rise in its total $\mathrm{N}$ input compared to its tissue $\mathrm{N}$ content; and in comparison with black haricot bean which yielded the lowest levels of DM and total $\mathrm{N}$. Similar contributions of biomass production to the total $\mathrm{N}$ inputs were observed by Wagger (1989) and Teasdale et al. (2004) in hairy vetch. The difference in the tissue $\mathrm{N}$ concentration and total $\mathrm{N}$ inputs between the species could, therefore, be attributable to differential potential biomass productivity and $\mathrm{N}_{2}$-fixation ability of the species (Odhiambo and Bomke, 2001; Njunie et al., 2004). Moreover, in plants grown on low-N field soils, like that of this study (Table 1), the total plant or biomass $\mathrm{N}$ contribution could be attributable to $\mathrm{N}$ derived from the $\mathrm{N}_{2}$-fixation (Wolyn et al., 1989). 



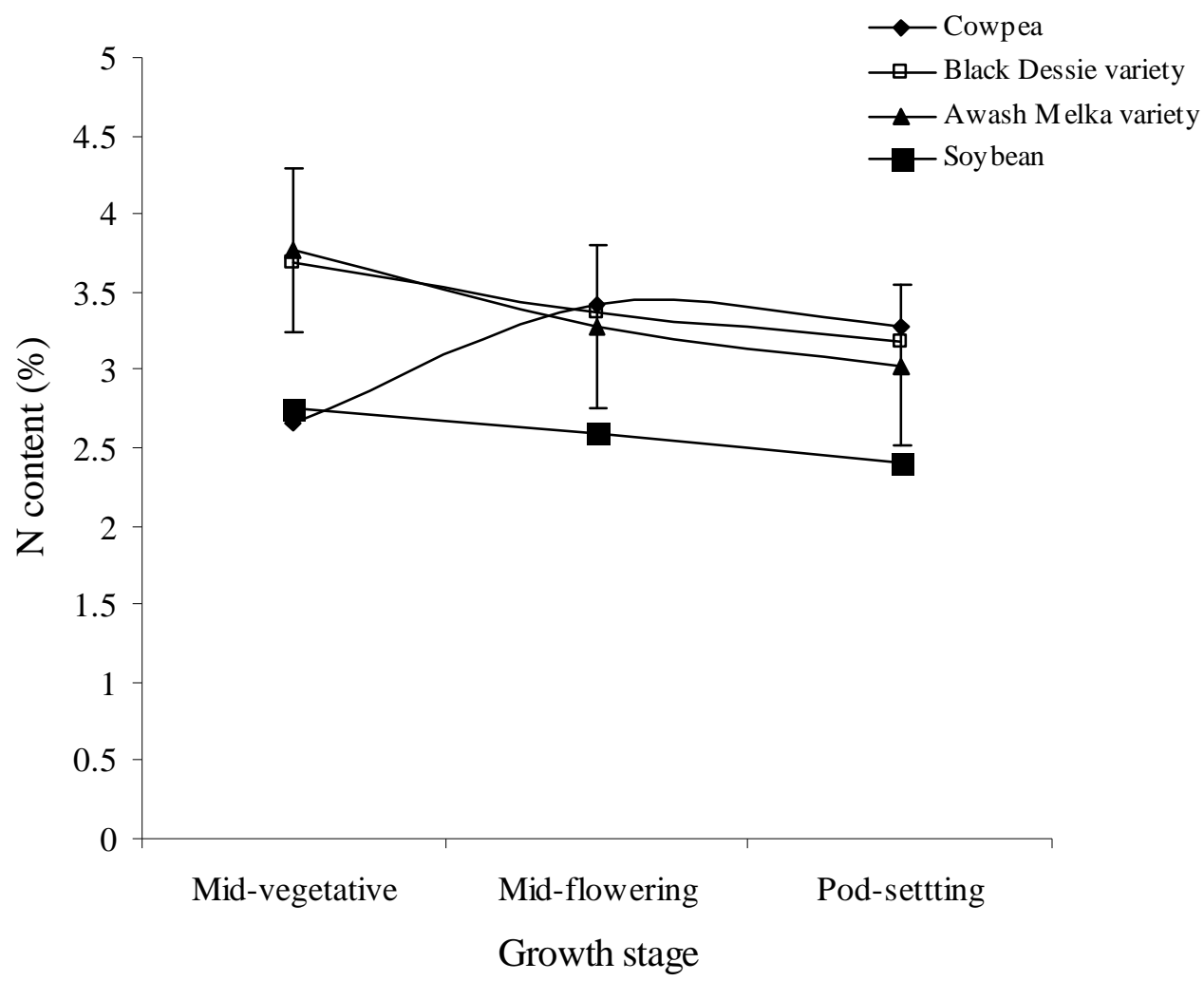

Figure 3. Interaction effect of species and growth stage on shoot tissue $\mathrm{N}$ content (\%) Vertical bars represent LSD values for interaction effect at $1 \%$ probability level.

Growth stage of the GM legumes at termination was also found to significantly $(\mathrm{P} \leq 0.01)$ affect the total $\mathrm{N}$ input following the pattern similar to its effect on total DM production, as indicated by a highly significant correlation between them $(\mathrm{r}=0.93)$. The maximum $\mathrm{N}$ input (43.17 $\mathrm{kg} \mathrm{ha} \mathrm{h}^{-1}$ ) was recorded during the latter stage of termination (pod-setting) at which DM yield attained its peak (1.42 $\mathrm{t} \mathrm{ha}^{-1}$ ) (Table 5 and 8). Kong et al. (1993) reported similar observations, stating that the amount of $\mathrm{N}$ provided by the GM crops varied according to the growth stage at the time of incorporation, corresponding to the biomass production. Ranells and Wagger (1992) in North Carolina, however, reported an opposing trend in crimson clover, where the $\mathrm{N}$ input declined as $\mathrm{DM}$ production increased with the maturity of crimson clover from the late vegetative to early seed set growth stages.

Since the $\mathrm{N}$ accumulation is a major determinant of the ability of organic residues to supply nutrients, though there are other modifying factors (Myers et al., 1994), cowpea at the mid-flowering stage of growth could be considered a superior GM crop to provide GM-N. This result corroborates the results reported by Odhiambo and Bomke (2001), who observed peak $\mathrm{N}$ inputs at the flowering stage of growth while examining the potential of crimson clover (Trifolium incarnatum L.) and narrow leaf vetch (Vicia angustifolia L.) as legume green manure.

Table 8. Species and growth stage effects on estimated total nitrogen input (kg ha-1).

\begin{tabular}{lllll}
\hline & \multicolumn{2}{l}{ Growth stage (GS) } & & \\
\cline { 2 - 4 } Legume species (LS) & Mid-vegetative & Mid-flowering & Pod-setting & Mean \\
\hline Cowpea & 42.67 & 71.23 & 62.49 & $58.80 \mathrm{a}$ \\
Common bean $^{1}$ & 22.59 & 26.34 & 39.59 & $29.81 \mathrm{~b}$ \\
Common bean $^{2}$ & 33.99 & 31.53 & 28.43 & $31.32 \mathrm{~b}$ \\
Soybean & 33.14 & 34.20 & 42.19 & $36.51 \mathrm{~b}$ \\
\hline Mean & $33.10 \mathrm{~b}$ & $40.83 \mathrm{ab}$ & $43.17 \mathrm{a}$ & \\
\hline LSD & LS & GS & & \\
\hline$(0.01)$ & 13.4 & NS & & \\
$(0.05)$ & - & 8.53 & & \\
\hline
\end{tabular}

Means within a row or column followed by the same letter are not significantly different at the specified probability levels.

${ }^{1}$ Black Dessie V ariety, ${ }^{2}$ Awas Melka V ariety. 
Table 9. Correlation coefficients between growth parameters of green manuring legume crops.

\begin{tabular}{|c|c|c|c|c|c|c|}
\hline Parameters & NTN & WTN & NEN & WEN & TDM & TNI \\
\hline NTN & 1 & $0.85^{* *}$ & $0.91 * *$ & $0.79 * *$ & $0.37^{*}$ & $0.44 * *$ \\
\hline WTN & & 1 & $0.80^{* *}$ & $0.75^{* *}$ & $0.34^{*}$ & $0.49 * *$ \\
\hline $\mathrm{NEN}$ & & & 1 & $0.90 * *$ & $0.40^{*}$ & $0.49 * *$ \\
\hline WEN & & & & 1 & $0.39 *$ & $0.48^{* *}$ \\
\hline TDM & & & & & 1 & $0.93^{* *}$ \\
\hline TNI & & & & & & 1 \\
\hline
\end{tabular}

\subsubsection{Phosphorus and Potassium Compositions and} Inputs

In this study significant interaction $(\mathrm{P} \leq 0.05)$ of the species according to growth stage treatments was observed in tissue $\mathrm{P}$ concentration (Table 4), where Awash Melka variety showed an increase followed by a decrease at and after the mid-flowering stage of growth. Tissue $\mathrm{P}$ concentration in soybean, however, showed a marginal and linear decrease as termination was delayed (Figure 4). After considering the total $\mathrm{P}$ input of green manure, a significant difference $(\mathrm{P} \leq 0.01)$ between species was observed, where cowpea contributed the highest amount (6.84 kg P ha-1) (Table 10). The total P input, however, was not found to vary $(\mathrm{P}>0.05)$ due to growth stage effect.

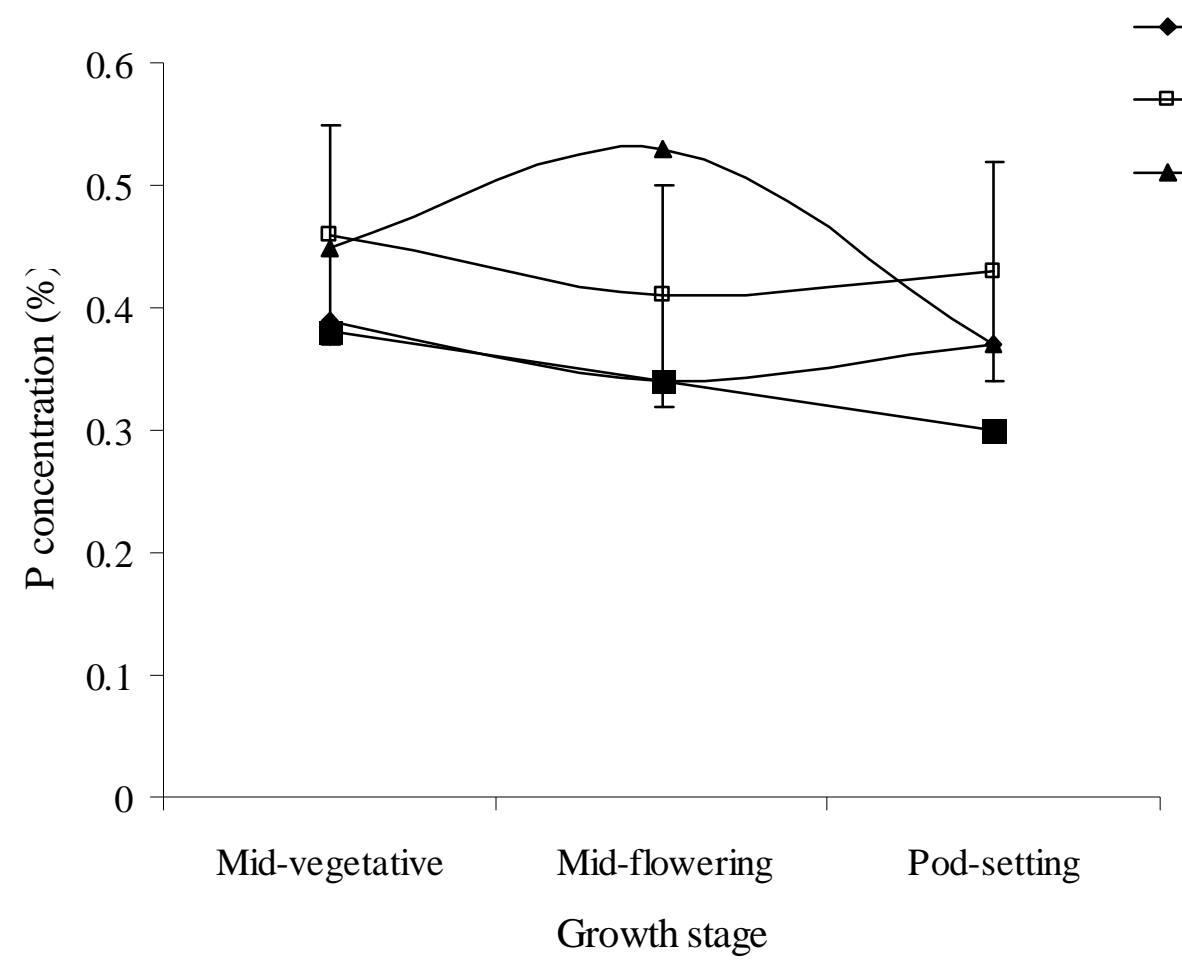

Figure 4. Interaction effect of species and growth stage on shoot P concentration (\%) Vertical bars represent LSD values for interaction effect at 5\% probability level.

Even though the shoot $\mathrm{K}$ concentration of GM crops in this study was found to be non-significant $(\mathrm{P}>0.05)$, growth stage at termination was observed to significantly affect $(\mathrm{P} \leq 0.05)$ the tissue $\mathrm{K}$ concentration (Table 4 ). Declining trends of shoot $\mathrm{K}$ composition in the subsequent samplings of GM legumes right after the initial termination observed in this study (Figure 5) were found to be in agreement with the findings of Franchini et al. (2003) and Njunie et al. (2004) who reported higher K contents from foliage of legume crops during earlier stages of growth. In spite of the non-significant species difference in tissue $\mathrm{K}$ concentration observed in this study, significant differences $(\mathrm{P} \leq 0.05)$ between the legume crops were, however, recorded in total $\mathrm{K}$ input, where cowpea contributed the highest amount $(24.02 \mathrm{~kg}$ $\mathrm{K} \mathrm{ha}^{-1}$ ) (Table 10). Growth stage of green manure crops at soil incorporation did not cause significant differences $(\mathrm{P}>0.05)$ in total $\mathrm{K}$ input. 


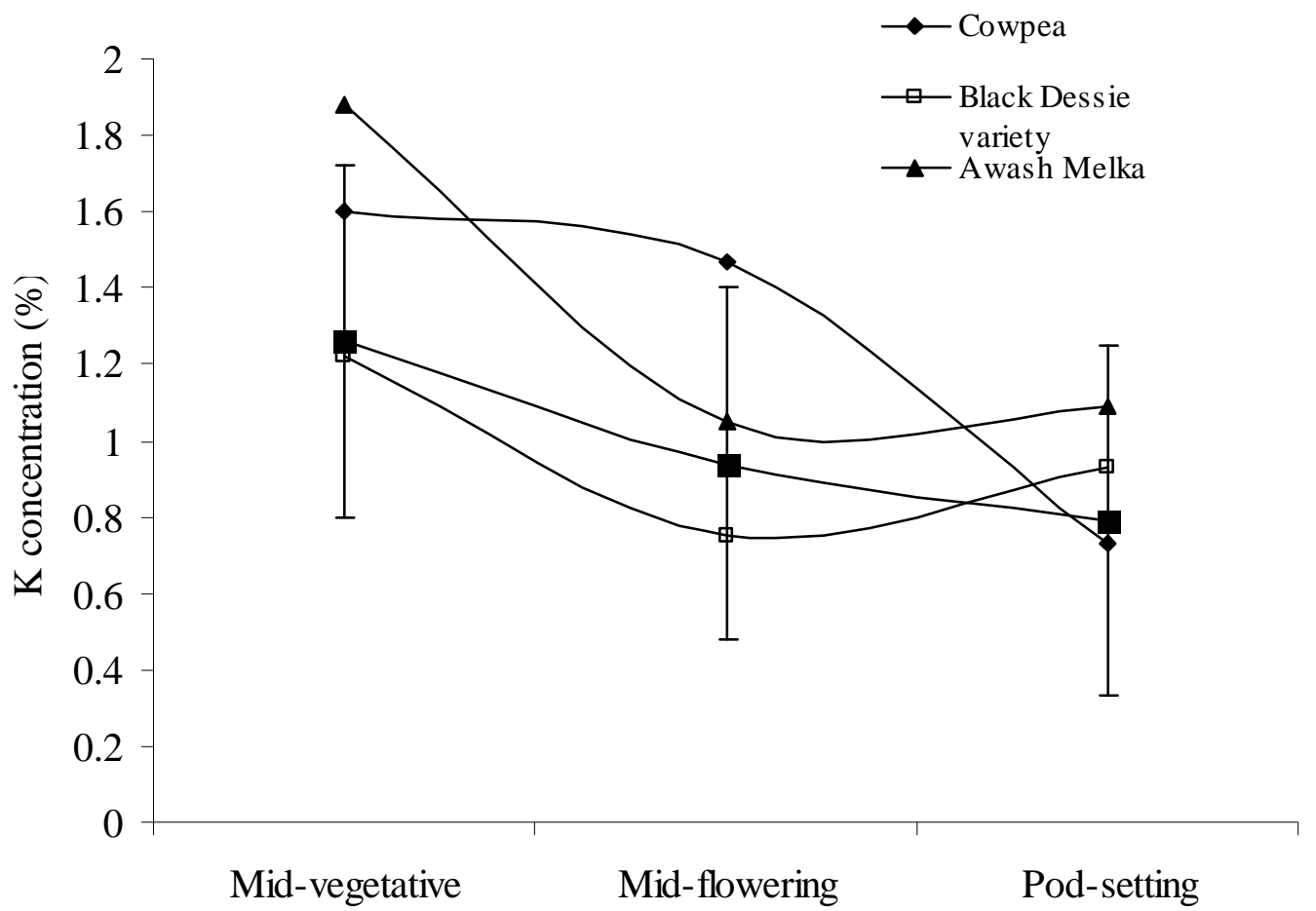

Growth stage

Figure 5. Effect of growth stage of legumes at incorporation on tissue K concentration (\%) Vertical bars represent LSD value for growth stage effect at $5 \%$ probability level.

\subsubsection{Effect on Calcium Composition and Input}

In comparison to other plant nutrients considered in this study, the widest range of concentration in legume shoot materials were recorded for $\mathrm{Ca}$. Tissue $\mathrm{Ca}$ concentration was observed to vary between the GM crops which ranged between 2.79 and $4.37 \%$ where soybean and cowpea recorded the lowest and the highest values, respectively (Table 11). At varying stages of plant growth, however, the $\mathrm{Ca}$ concentration in the tissue was not found $(\mathrm{P}>0.05)$ to vary statistically. Maschner (1995) on the other hand, has reported that the Ca content of plants varies at between 0.1 and $>0.5 \%$ of tissue dry weight depending on the growing condition, plant species and plant organ. While determining the total Ca input of the GM legumes in this study, significant difference $(\mathrm{P} \leq 0.01)$ was also observed between GM crops, where cowpea contributed the highest amount (79.38 $\mathrm{kg} \mathrm{Ca} \mathrm{ha-1)}$. Difference in total Ca input was also observed due to the effect of growth stage at termination, where an increase in the overall $\mathrm{Ca}$ input was observed as termination was delayed (Table 11).

Table 10. Species effect on estimated total phosphorus and potassium inputs $\left(\mathrm{kg} \mathrm{ha}^{-1}\right)$.

\begin{tabular}{|c|c|c|c|c|}
\hline \multirow[b]{2}{*}{ Legume species (LS) } & \multicolumn{3}{|c|}{ Growth stage (GS) } & \multirow[b]{2}{*}{ Mean } \\
\hline & Mid-vegetative & Mid-flowering & Pod-setting & \\
\hline \multicolumn{5}{|l|}{ Phosphorus $(\mathrm{P})$} \\
\hline Cowpea & 6.24 & 7.19 & 7.13 & $6.84 a$ \\
\hline Common bean ${ }^{1}$ & 2.86 & 3.19 & 5.34 & $3.86 \mathrm{~b}$ \\
\hline Common bean ${ }^{2}$ & 4.04 & 4.97 & 3.47 & $4.16 \mathrm{~b}$ \\
\hline Soybean & 4.16 & 4.47 & 5.25 & $4.76 \mathrm{~b}$ \\
\hline Mean & 4.45 & 4.95 & 5.32 & \\
\hline \multicolumn{5}{|l|}{ Potassium (K) } \\
\hline Cowpea & 29.28 & 28.95 & 13.84 & $24.02 \mathrm{a}$ \\
\hline Black Dessie & 7.69 & 5.84 & 11.74 & $8.42 \mathrm{~b}$ \\
\hline Awash Melka & 16.74 & 9.91 & 10.21 & $12.29 \mathrm{~b}$ \\
\hline Soybean & 15.51 & 12.67 & 13.85 & $14.01 \mathrm{ab}$ \\
\hline Mean & 17.31 & 14.34 & 12.42 & \\
\hline LSD & LS (P) & $\mathrm{GS}(\mathrm{P})$ & LS (K) & GS $(K)$ \\
\hline$(0.01)$ & 1.19 & NS & 10.24 & NS \\
\hline$(0.05)$ & - & NS & - & NS \\
\hline
\end{tabular}

Means within a column followed by the same letter are not significantly different at the specified probability levels.

${ }^{1}$ Black Dessie V ariety, ${ }^{2}$ Awas Melka V ariety. 
Table 11. Species and growth stage effects on tissue Ca concentration and total input $\left(\mathrm{kg} \mathrm{ha}^{-1}\right)$.

\begin{tabular}{|c|c|c|c|c|}
\hline \multirow[b]{2}{*}{ Legume species (LS) } & \multicolumn{3}{|c|}{ Growth stage (GS) } & \multirow[b]{2}{*}{ Mean } \\
\hline & Mid-vegetative & Mid-flowering & Pod-setting & \\
\hline \multicolumn{5}{|c|}{ \% Ca concentration (CC) } \\
\hline Cowpea & 2.21 & 4.30 & 5.61 & $4.37 \mathrm{a}$ \\
\hline Common bean ${ }^{1}$ & 2.58 & 1.91 & 2.62 & $2.37 \mathrm{~b}$ \\
\hline Common bean ${ }^{2}$ & 2.86 & 3.49 & 3.04 & 3.13ab \\
\hline Soybean & 2.20 & 3.23 & 2.93 & $2.79 \mathrm{~b}$ \\
\hline Mean & 2.72 & 3.23 & 3.55 & \\
\hline \multicolumn{5}{|c|}{ Total Ca (TC) input $\left(\mathrm{kg} \mathrm{ha}^{-1}\right)$} \\
\hline Cowpea & 46.86 & 85.58 & 105.69 & $79.38 \mathrm{a}$ \\
\hline Common bean ${ }^{1}$ & 16.08 & 14.72 & 32.69 & $21.16 \mathrm{~b}$ \\
\hline Common bean ${ }^{2}$ & 26.19 & 34.03 & 28.67 & $29.61 \mathrm{~b}$ \\
\hline Soybean & 26.84 & 43.38 & 51.75 & $40.66 \mathrm{~b}$ \\
\hline Mean & $28.99 \mathrm{~b}$ & $44.43 \mathrm{a}$ & $54.68 \mathrm{a}$ & \\
\hline LSD & LS (CC) & GS(CC) & LS(TC) & $\mathrm{GS}(\mathrm{TC})$ \\
\hline$(0.01)$ & 1.35 & NS & 20.49 & NS \\
\hline$(0.05)$ & - & NS & - & 13.06 \\
\hline
\end{tabular}

Means within a row or column followed by the same letter are not significantly different at the specified probability levels.

${ }^{1}$ Black Dessie V ariety, ${ }^{2}$ Awas Melka V ariety.

\section{Conclusion}

The nutrient contents of shoot tissues, mainly N, P and K varied according to GM crops which generally decreased with increasing plant age, confirming that the nutritional inputs of green manuring crops depend on the species and age at termination. The total $\mathrm{N}$ input of the GM legumes was found to be significantly affected by growth stage at termination, where termination at early (midvegetative) stage of growth contributed the lowest total $\mathrm{N}$, whereas the latest stage of termination contributed the maximum. From the results of this study, it could, therefore, be concluded that cowpea used as green manure if incorporated into soil at its flowering stage of growth may generally be promising in the nutrient cycling potential of crops as it could make available the largest amount of plant nutrients, namely organic matter, N, P, $\mathrm{K}$ and $\mathrm{Ca}$, compared to the rest, owing to deep rooting characteristics and biomass production. In this regard, further delay in the termination of cowpea beyond the flowering stage of growth could result in no additional benefit with respect to total $\mathrm{N}$ input from the phytomass.

\section{Acknowledgment}

The authors thank the National Soil Testing Center for carrying out most of the plant tissue analysis. Special gratitude is also extended to Mr. Ahmed Nasser for giving his consent to use the laboratory service, and Mr. Werkineh Kumsa for overseeing the field activities and collecting data during the course of the study.

\section{References}

AOAC (Association of Office Analytical Chemist). 1994. Official method of analysis. $12^{\text {th }}$ Edition. Washington DC.

Bohlool, B.B., Ladha, J.K., Garrity, D.P. and George, T. 2004. Biological nitrogen fixation for sustainable agriculture: A perspective. Plant and Soil 141(1-2): 1-11.
Brandt, S.A. 1996. Alternatives to summer fallow and subsequent wheat and barley yield on a Dark Brown soil. Canadian Journal of Plant Science 76: 223-228.

Bumaya, A.H. and Naylor, D.V. 1988. Phosphorus sorption and extractability in Andic soil incubated with plant residues of variable P content. Plant and Soil 112: 77-81.

Cavigelli, M.A. and Thien, S.J. 2003. Phosphorus bioavailability following incorporation of green manure crops. American Journal of Soil Science 67: 1186-1194.

Cherr, C.M., Scholberg, J.M.S. and McSorley, R. 2006. Green manure approaches to crop production: A synthesis. Agronomy Journal 98: 302-319.

Cline, G.R. and Silvernail, A.F. 2001. Residual nitrogen and kill date effects on winter cover crop growth and nitrogen content in a vegetable production system. Hort Technology 11: 219-225.

Dahlin, S., Kirchmann, H., Kätterer, T., Gunnarsson, S. and Bergström. L. 2005. Possibilities for improving nitrogen use from organic materials in agricultural cropping systems. AMBIO: A Journal of the Human Environment 34(4): 288-295.

EARO (Ethiopian Agricultural Research Organization). 1999. Distribution of Existing Research Centers by AgroEcological Zones. Addis Ababa, Ethiopia.

Elahi, N.N., Akhtar, W. and Mirza, J.I. 2004. Effect of combined nitrogen on growth and nodulation of two mungbean (Vigna radiata [L.] wilczek) cultivars. Journal of Research Science 15(1): 67-72.

Franchini, J.C., Hoffmann-Campo, C.B., Torres, E., Miyazawa, M. and Pavan, M.A. 2003. Organic composition of green manure during growth and its effect on cation mobilization in an Acid Oxisol. Communications in Soil Science and Plant Analysis 34(13-14): 2045- 2058.

Gwata, E.T., Wofford, D.S., Boote, K.J. and Mushoriwa, H. 2003. Determination of effective nodulation in early 
juvenile soybean plants for genetic and biotechnology studies. African Journal of Biotechnology 2(11): 417-420.

Horst, W.J., Kamh, M. Jibrin, J.M. and Chude, V.O. 2001. Agronomic measures for increasing $\mathrm{P}$ availability to crops. Plant and Soil 237: 211-223.

Isse, A.A., MacKenzie, A.F., Stewart, K., Cloutier, D.C. and Smith, D.L. 1999. Cover crops and nutrient retention for subsequent sweet corn production. Agronomy Journal 91: 934-939.

Johnson, H.S. and Hume, D.J. 19783. Comparisons of nitrogen fixation estimates in soybeans by nodule weight, leghemoglobin content, and acetylene reduction. Canadian Journal of Microbiology 19: 11651168.

Kong, T., Robinson, D.L. and Savoy Jr, H.J. 1993. Soil nitrogen and carbon status following clover production in Louisiana. Communications in Soil Science and Plant Analysis 24: 1345-1357.

Li, G.C., Mahler, R.L. and Everson, D.O. 1990. Effects of plant residues and environmental factors on phosphorus availability in soils. Communications in Soil Science and Plant Analysis 21: 471-491.

Marschner, H. 1995. Mineral Nutrition of Higher Plants, $2^{\text {nd }}$ edition. Academic Press, London.

Martin, J.H., Leonard, W.H. and Stamp, D.L. 1976. Legumes. In: Martin, J.H., Leonard, W.H. and Stamp, D.L. (eds.). Principles of Field Crop Production. Macmillan Publishing, New York, USA. pp. 621-788.

Myers, R.J.K, Palm, C.A., Cuevas, E., Gunakillrke, I.U.N. and Brossard, M. 1994. The synchronization of nutrient mineralization and plant nutrient demand. In: Woomer, P.L. and Swift, M.G. (eds.). Biological Management of Soil Fertility. Wiley-Sayce Co-publication, New York, USA. pp. 81-116.

Nair, K.P.P. 1996. The buffering power of plant nutrients and effects on availability. Advances in Agronomy 57: 237287.

Njunie, M.N., Wagger, M.G. and Luna-Orea, P. 2004. Residue decomposition and nutrient release dynamics from two tropical forage legumes in a Kenyan environment. Agronomy Journal 96: 1073-1081.

Odhiambo, J.J.O. and Bomke, A.A. 2001. Grass and legume cover crop effects on dry matter and nitrogen accumulation. Agronomy Journal 93: 299-307.

Prasad, P.V.V., Satyanarayana, V. Murthy, V.R.K. and Boote, K.J. 2002. Maximizing yields in rice-groundnut cropping sequence through integrated nutrient management. Field Crops Research 75: 9-21.

Ranells, N.N. and Wagger, M.G. 1992. Nitrogen release from crimson clover in relation to plant growth stage and composition. Agronomy Journal 84: 424-430.
Ratilla, B.C. and Escalada, R.G. 2006. Time of incorporation of field legume herbage and its influence on the growth and yield of upland rice. Annuals of Tropical Research 28(2): 12-31.

Rhoades, J.B. 1982. Cation exchange capacity. In: Page, A.L. (ed.). Method of Soil Analysis. Part 2: Chemical and microbiological properties. American Society of Agronomy Madison, Wisconsin, USA. pp. 149-158.

Sainju, U.M. and Singh, B.P. 2001. Tillage, cover crop, and kill-planting date effects on corn yield and soil nitrogen. Agronomy Journal 93: 878-886.

Sanginga, N., Thottappilly, G. and Dashiell, K. 2000. Effectiveness of rhizobia nodulating recent promiscuous soybean selections in the moist-savanna of Nigeria. Soil Biology and Biochemistry 32: 127-133.

Somado, E.A. and Sahrawat, K.L. 2007. Biomass and nitrogen accumulation by green manure legumes as affected by phosphate rock in submerged soils. African Journal of Agricultural Research 2 (1): 1-6.

Swaraj, K. and Garay, O.P. 1977. The effect of aging on the leghemoglobin of cowpea nodules. Physiology of Plant 39: 185-189.

Tandojam, S.M.A. 2002. Organic manuring and agriculture. Pakistan Economist. (http://www.pakistanec onomist.com) (Accessed on May 27, 2007).

Teasdale, J.R., Devine, T.E., Mosjidis, J.A., Bellinder, R.R. and Beste, C.E. 2004. Growth and development of hairy vetch cultivars in the northeastern United States as influenced by planting and harvesting date. Agronomy Journal 96: 1266-1271.

Uratani, A., Daimon, H., Ohe, M., Harada, J., Nakayama, Y. and Ohdan, H. 2004. Ecophysiological traits of field grown Crotalaria incana and C. pallida as green manure. Plant Production Science 7(4): 449-455.

Wagger, M.G. 1989. Time of desiccation and plant composition and subsequent nitrogen release from several winter annual cover crops. Agronomy Journal 81: 236-241.

Wivstad, M. 1996. Green-Manure Crops as a Source of Nitrogen in Cropping Systems. PhD Thesis presented to Swedish University of Agricultural Sciences, Uppsala, Sweden.

Wolyn, D.J., Attewell, L.J., Ludden, P.W. and Bliss, F.A. 1989. Indirect measures of $\mathrm{N}_{2}$ fixation in common bean (Phaseolus vulgaris L.) under field conditions: The role of lateral root nodules. Plant and Soil 113: 181-187.

Yadav, R.L., Dwivedi, B.S. and Pandey, P.S. 2000. Ricewheat cropping system: Assessment of sustainability under green manuring and chemical fertilizer inputs. Field Crops Research 65: 15-30. 